\title{
Two Concepts of Human Rights in Contemporary Korea
}

\author{
Cho Hyo-Je I Free University Berlin and SungKongHoe University Seoul
}

The paper looks at the emergence of two distinct concepts of human rights in contemporary Korea. The first, more time-tested concept draws upon the historical experience of pro-democracy movements dating back to the 1970s. The second concept is seen to be a relatively new phenomenon which started as a less conspicuous counterdiscourse of human rights of the past but has gained some prominence in recent years. The divergence of the human rights concept along the two different narratives has had ramifications far beyond the confines of domestic human rights promotion. It is argued that the contrasting concepts have evolved and taken shape over the years following the 1987 democratization. Several broad trends and events in the post-democratization period have helped the competing concepts to develop their distinctive contours and to bring their respective policy options into sharper focus. The contributing trends are four-fold: first, the institutionalization of human rights; second, changes in perceived relationship between human rights and democracy, and the proliferation of rights discourse; third, the predominance and penetration of a neoliberal economic doctrine in many spheres of the society; and fourth, the internationalization of the North Korean human rights issue. The corollary of this trend is the bifurcation between the two seemingly irreconcilable concepts of human rights, i.e. the maximalist, civil society-oriented concept versus the minimalist, less liberal internationalist human rights concept. Each of the two has its own share of strengths and weaknesses. The future of human rights in Korea is likely to depend upon the interplay between, and the possible reconfiguration of, these two concepts.

Keywords: human rights concept, democracy, maximalist, minimalist, Korea 


\section{Introduction}

By the time the former authoritarian regime gave way to more pluralist democratic politics in Korea after the late 1980s the concept of human rights was almost synonymous with the typical notion of human rights as the individual's last resort against the state's repression. Resonated time and again in the public understanding of human rights before the 1987 watershed was the theme of defending human dignity in the face of the state's blatant disregard for the freedom of citizens. As described in the preamble of the Universal Declaration of Human Rights, "recognition of the inherent dignity and of the equal and inalienable rights of all" was indeed seen to be "the foundation of freedom, justice and peace" by the public. Such was the draconian nature of human rights abuses during the authoritarian period that the narrative of human rights at the time revolved around a straightforward, almost homogeneous interpretation: human rights must be an end to and a valuable means for democracy and also a protective shield against arbitrary deprivation of human life and respect (Kim, 2001). To the extent that the 'mainstream' or 'traditional' view of human rights was clearly defined, however, there were very few, if any, coherent counter-arguments against the prevailing concept. While the former was abundantly documented and reported (cf. Amnesty International, 1986; Asia Watch Committee, 1987; Ranard, 1980), the latter existed only as a rather defensive argument based on the 'necessary evil' logic under the circumstances of political exigency ("The temporary suspension of human rights may be justified in the face of the national security threat.") or as conservatives' vague antithetical sentiment against 'rights talk' ("Human rights advocates are trouble-makers at best and communist bedfellows at worst."). This meant that although there were severe restrictions on citizens' freedom in all their guises in the past there existed a largely undisputed ideal of 'universal' human rights. This is an interesting point of departure from a more articulated, albeit flawed, form of counterconcept of human rights such as the one illustrated by the so-called Asian value' debate (Bell, 1996; Kim, 1994; Zakaria, 1994). In short, the conceptual landscape of human rights in Korea in the 1980s consisted of a rather clearcut, standard formulation of human rights as liberty-equality-fraternity on the one hand, and of a merely reactive and somewhat temperamental inclination against the rights discourse on the other, hence the vastly asymmetrical picture.

The contemporary landscape of human rights in Korea, however, is an 
altogether different story; it has greatly departed from the earlier picture. Nowadays two different concepts of human rights compete and clash with each other, literally as well as metaphorically, in conference halls, in the corridors of power and indeed in the streets. Virtually no political controversy today seems to escape from these antagonistic concepts of human rights. Nowhere has this tension been more dramatically highlighted than the recent incidents including the months-long candlelight protests across the country in the spring of 2008 just after a new conservative government was installed, and the killings of civilians and riot police in the downtown Seoul over the forced eviction operation related to an urban redevelopment project. Not only did human rights community cry out for justice in these occasions, but also a sort of counter-argument of human rights presented itself with more assertiveness and less inhibition - a subtle but very significant change compared to the past. A hasty answer to why this kind of change has occurred might be easily framed as the pro-human rights versus anti-human rights antagonism. But one needs to go beyond this simplistic interpretation and search for a more nuanced, socio-historically informed clue, since there are multi-faceted collaborating factors which have eventually led to the present change.

It is often claimed that the modern discourse of human rights is historically specific (Ishay, 2004) and socially constructed (Stammers, 1999), that it has acquired a hegemonic status in international politics (Donnelly, 2003), and that it has become part and parcel of democratic politics (Beetham, 1999). Also from the perspectives of political ideologies the concept of human rights has been subject to diverse interpretation ranging from the classical liberalism (Cranston, 1967), to John Humphrey's "humanitarian liberalism with social democracy" (Sears, 2005), and to social democratic welfarism (Donnelly, 2003) or socialism (Teeple, 2005). Despite the diverse perspectives and interpretations of human rights there appear to be certain common denominators over the concept: in terms of ontology it aims to respect irreducible human dignity and equal worth for every human being (Donnelly, 1982); in terms of human nature it recognizes human beings as ultimately valuing either liberty or interest or both (Fagan, 2009); in terms of the role of society it emphasizes both the state's duties of restraint and its positive duties, and the need to optimize both (Fredman, 2008); and in terms of epistemology and method for attainment it pursues diverse routes as universalizable legal norms and standards, non-legal compliance mechanisms and various civil society activism linked up with global solidarity movement (Steiner et al., 2007). It is noteworthy that both the contrasting concepts of 
human rights in contemporary Korea share some overlapping consensus with this common ground, but at the same time, have deviated from it to varying degrees one way or another. This in turn proves the previously stated point that the human rights discourse is indeed a historically specific and socially constructed entity.

With these in mind the objectives of this paper can be stated as threefold: first, how and why the two different, competing concepts of human rights have emerged in South Korea in the relatively short period of time since the late 1980s; second, what are the characteristics of these two concepts?; and third, what implications do they have for the promotion of human rights in contemporary Korea? In what follows I shall argue that the combination of policy changes, political contingencies and socio-economic conditions has acted as an important filter through which the different discourses of human rights have been tested, advocated and facilitated, resulting in the emergence of different human rights concepts. These sociohistorical catalysts include the institutionalization of human rights discourse; changes in perceived relationship between human rights and democracy, and the proliferation of rights discourse; the penetration of neoliberal economic doctrine in many spheres of society; and the internationalization of the North Korean human rights issue. In what follows each of these contributing factors will be discussed in turn with no particular chronological order.

\section{Institutionalization of Human Rights}

It has long been accepted that human rights discourse in Korea in its modern manifestation was borne out of the situation since the early 1970s when clashes between the authoritarian state repression and the civil society's resistance began to escalate. The resulting democratization in the 1980s ushered in a new era of democratic consolidation and the institutionalization of human rights. This received common view has been recently challenged by Lee (2008) that although human rights as a fully-fledged protest idea for prodemocracy movement rose to prominence after the 1970s the process of the internalization and socialization of the human rights concept in the broader sense had already been set in motion immediately following the Liberation in 1945 which lasted until the early 1970s with a measure, albeit limited, of institutional arrangement. So in this sense the institutional path after the 1987 democratization may well be described as the 'second wave' of institutionalization of human rights. The more recent move was firmly 
anchored in democratic ideal and aspiration but the progress was arduous and with plenty of controversies and conflicts: it could be stated that the road to official recognition of human rights fully gathered momentum during the presidencies of Kim Dae-Jung (1998-2003) and Roh Moo-Hyun (2003-2008), respectively. A number of institutionalized human rights can be identified. Among them was the creation of the National Human Rights Commission in 2001, perhaps the most symbolic, visible and tangible result of the institutionalization of human rights. Originally floated as an election pledge by Kim Dae-Jung the proposal was materialized as a statutory body with a permanent secretariat after, and with the help of, massive civil society campaigns. Independent and plural in nature, the organization has been at the forefront of placing human rights at the center of public life by acting as "the independent power monitor, low-cost high-speed and fair investigator and relief giver, expert policy advisor, and sensitive and effective human rights educator." (Kwak, 2006: 188). The 'policy recommendation', the organization's primary means of enforcing its decision, is found to have had some notable, quantifiable effect on the criminal justice system, though not without limitations due to its non-binding nature (Lee, 2007b). The national body's existence and its work have also carried particularly symbolic importance since it is perceived by many as a quasi-civil society representative entity - a 'watchful eyepiece within the government behemoth', to borrow a commentator's analogy - implanted on the hostile bureaucratic soil, facilitating the interchanges between the officialdom and civil society over human rights issues (Kwak, 2002). Another example of the institutionalization of human rights includes attempts to look into the human rights abuses committed in the past. For the first time some of the past atrocities which had been virtually a taboo subject were openly revisited and discussed in public, with historical incidents of sensitive nature increasingly becoming subject of heated debate in academia as well as in the media. Not only did this new openness lead to more public awareness of the nation's recent past, but also it helped formulate constructive ways to heal the 'old wounds' and to bring the painful memories to a dignified public closure (Suh, 2007b). After the long political controversies the state apparatus including the judiciary began reviewing past human rights violation cases which culminated in the establishment of the Truth and Reconciliation Commission in 2005. The temporary official body was broadly mandated to investigate past atrocities related to the Japanese colonial rule, the Korean War, the authoritarian repression, and so forth. Alongside this, separate investigative bodies were set up along the lines of specific issues such as unaccounted death cases or the 
Jeju island massacres of the late 1940s. Also created were some particular truth committees under the auspices of various government bodies including the police, the defense ministry and the security agency. These changes coincided with an 'history movement' which attempted to interpret the nation's recent history not from the perspective of the power-that-be but from that of the oppressed and the dispossessed. In addition, a move to disseminate the idea of human rights through the formal educational curriculum became another manifestation of the institutionalization of human rights. A variety of social issues such as workers' rights, rights of the child and the student, sexual harassment, rights of the conscripts, and the check against arbitrary power of the law enforcement personnel started to be included in different levels of the educational institution. With the rise in interest in human rights education came the introduction of human rightscompatible curriculum at different levels of schools with possible collaboration between schools and universities (Chun, 2008) and also a more attention to the attitudes and beliefs concerning human rights than a mere pursuit of legally sanctioned rights (Heo, 2008). There were attempts to make human rights education mandatory for, among others, the military, the police, and the immigration officials. Although the policy changes were haphazard and slow the very fact that such an education was ever attempted at all would have been inconceivable just a few years ago.

The traditional human rights movement has engaged with the above changes enthusiastically. The human rights movement, as well as prodemocracy civic activities in general, not only have been influenced by the institutionalization drive of human rights, but they have also become an important driver of the institutionalization process itself. It is often pointed out that Korean politics has a distinctive feature of 'movement politics' with heavy inputs from civil society, ideationally as well as in terms of personnel (Cho, 2000). Through this process the traditional discourse managed to become one of the important pillars of the governing ideology the successive governments of Kim Dae-Jung and Roh Moo-Hyun relied upon. Indeed the Kim administration described itself as 'the people's government'; and also that of Roh had presented itself as 'the participatory government', with both of them announcing to pursue a 'human rights-respecting nation'. This change in official language and policy, although far from flawless, had a profound impact on the bureaucracy in general; the discourse of human rights was allowed to penetrate into the hitherto forbidden core of the old establishment. For example, it was in this context that the archives of some security apparatus including the National Intelligence Service were made 
open for the first time to the truth committees that investigated cases of the past human rights abuses. This in turn had transforming effect on the human rights, since the institutionalization inevitably required human rights advocates and discourse to be subject to bureaucratic rule, regulations, and organizational constraints. Human rights community had to learn the art of governing' and, in many cases, had to allow institutionalized human rights policies to be held accountable to the normal organizational process, including a call for more public scrutiny on matters concerning budgetary control.

On the one hand, the institutionalization of human rights predictably further undercut the counter-discourse's room for maneuver. For at that time it was more difficult, if not impossible, for the counter-argument of human rights to make its case in the changed environment. But on the other hand the situation produced a rather paradoxical effect that the counter-discourse was able to acquire some policy leverage to scrutinize the traditional human rights movement with the very bureaucratic criteria the institutionalization was supposed to be subject to. This was most evidently demonstrated after the advent of the conservative Lee Myung-Bak government in 2008. Indeed the national human rights institution was forced to capitulate over the government's demand to trim down the personnel and activity level in line with the governmental overall drive to make a 'small government.' The onslaught on the institutionalized human rights using the bureaucratic organizational means proved to be an effective tactic on the part of the counter-discourse because the attack allowed the counter-discourse to criticize hegemony of the traditional human rights movement without having to oppose the human rights value in itself (Ju, 2007). The institutionalization of past history debate also generated conservative attack over the legitimacy and feasibility of rewriting history (Ahn, 2004; Grand National Party, 2004), which became more acrimonious after the Lee government (Han, 2009). Moreover, the counter-discourse successfully intervened to steer the national human rights institution for its own purposes, i.e. calling for the body to launch investigation into human rights abuses in North Korea. It is worth noting that some segment of the press and media has been at the forefront of this attack with the intellectual input from the conservative constituency.

\section{Proliferation of Human Rights and its Implication on Democracy}

With an increasing tendency towards institutionalization came 
proliferation of human rights discourse and movement. As pointed out in the above human rights during the authoritarian period was mainly seen to be struggle against the state's repression. As a result human rights at the time were conceptualized, perhaps understandably, exclusively under the rubric of civil and political rights. For the past two decades, however, this rather onedimensional understanding has been transformed into very divergent one to an unprecedented extent. There developed two contradictory but somehow related trends: a dramatic expansion of various human rights movements; and the proliferation of interest-based rights discourse and its associated collective action.

The human rights movement during the past twenty years has been expanded both in scale and in scope. All sorts of different issue areas of human rights ('horizontal dimension') have been brought into light with the corresponding formation of groups working for their respective causes. The concept of civil and political rights was fully endorsed, at least in theory, by the public and that of social, economic, cultural, and solidarity rights also began to be recognized among the wider audience. The speed with which this expansion has come about and the relative ease with which the public has accepted the basic tenets of these issues are remarkable. The most prominent among this trend were issues related to discrimination or, more precisely, to the struggle for 'recognition equality' by various subjugated social groups on account of different identities (Fraser and Honneth, 2003). Persons with disabilities have become increasingly visible in society in tandem with the rise in the public recognition and acceptance of their equality claims (Kim, 2008c). The disability issue was the first in a long list of 'recognition inequality', which was able to find a legislative solution (Nam, 2007). An interesting development is the 'discovery' of such sub-category within the disabled as the disabled women, an important insight into the double hardship of women with disabilities in a traditionally male-centered society (Cha, 2005; Hong and Sung, 2003). Also to be taken into account is the reality of the mentally disabled persons whose existence had been virtually hidden away from the public eye (Lee, 2007a). The plight of former patients of Hansen's Disease is another example of this resurfacing of long suppressed human rights issues (Jung, 2006). Discrimination based on one's sexual orientation has also been subject to heated public debate. As the lid on the taboo subject was lifted the protection of human rights for, and the endowment of full 'social' citizenship upon, those who are discriminated against on the basis of their sexuality began to be addressed in academia as well as in civil society (Seo, 2005). It is also discovered that there is a peculiar 
relationship between distorted masculinity and the suppressed sexuality within the military in a country where compulsory conscription policy is enforced for all male members of the public (Kwon, 2009). The protection of the elderly in a rapidly aging society - those over 65 years of age occupied $9.9 \%$ of all population as of 2007 and it is expected that the rate will rise to $20.8 \%$ by the year 2026 - has also been on the agenda of human rights movement (Yoo and Kang, 2008). In addition to issues related to 'recognition equality' there emerged new human rights issues based on the reinterpretation and radicalization of freedom. These include, among others, human rights of students and children (Cho, 2007), basic rights of the enlisted service personnel (Lee, 2005b), and the deprivation of education rights and persistent mental-physical abuse of the elite student-athletes (Kim, 2009b). The long-forgotten subject of those who are incarcerated on account of their conscientious objection to military conscription has been accepted as a public agenda on citizens' liberty in the last decade (Ahn and Jang, 2002; Lee, 2004b). Furthermore, new human rights issues reflecting the changed socio-economic circumstances under globalization such as rights of migrant workers have become important components of human rights movement (Gray, 2004; Seol, 2005). Almost all of these issues and problems had been neither recognized in public nor put on public agenda before democratization.

The expansion of human rights agenda was accompanied by the proliferation of interest-oriented rights discourse and its related collective action. How to respond to human rights claim motivated by 'self-interests' rather than by internationally recognized human rights standards is a challenging question (cf. Gearty, 2006). According to Lee (2004c) just as democratization process proceeded and deepened so came into being intense social conflicts in every aspect of public policy including, for example, nation-wide protests between professional groups over the boundary of their occupational control or selection of public work sites, etc. This was exacerbated by the some public attitude that interpreted democracy as mere interest-group advocacy (Jang et al., 2002). Collective action by people such as sit-ins or demonstrations was often taken to protest against the so-called 'undesirable facility' - a euphemism for institutions such as a halfway house for the homeless - which was planned to be constructed in a neighborhood. A recently published paper vividly chronicles the prolonged and fierce opposition, physical or otherwise, by certain community members to a proposed sports facility for the disabled on grounds of concern over the possible drop in property price in the neighborhood. The author of the study castigated the phenomenon as 'collective selfishness' disguised as 'rights 
advocacy' (Kim, 2009a). An exasperated human rights activist even suggested that "Human rights movement no longer deserves its name sake; it is now indistinguishable from material-interest movement." (Oh et al., 2007: 18). It has been pointed out that the proliferation of rights discourse should be understood in the context of sudden political openness after the longstanding oppression and of an inevitable empowering tendency of people who are promised democratic ideals and expanded entitlement, although that does not mean that we should confuse purely self-regarding action with fundamental human rights (Cho, 2002; Gearty, 2006).

The concurrent expansion of human rights movement and the proliferation of rights claim of all sorts have left significant impacts on the direction of post-democratization democracy in Korea. On the one hand, the closely intertwined discourse of democracy and human rights in the past was gradually and progressively separated. The hyphenated collocation of 'democracy-human rights' became increasingly less used as the governments of Kim Dae-Jung and Roh Moo-Hyun broadened the democratic constituencies. While debate on democracy was increasingly replaced by talks about 'post-democracy', human rights discourse was increasingly fragmented into myriad 'issue fightings' without much interconnecting common fabric linking the whole human rights community (weakening of 'vertical dimension' of human rights). The trend was somewhat slowed down only after the advent of Lee Myung-Bak government when some sections of population came to perceive that the retreat of democratic practices went hand in hand with gradual but inexorable chipping away of human rights. On the other hand, the grossly amplified rights claims and the public's general assertiveness may have helped steer the country's democracy away from a more inclusive, deliberative model towards something of a 'direct action democracy' model (cf. Carter, 2005). Traditional human rights discourse and movement may have contributed to these changes, perhaps unintentionally, which turned out to be a double-edged sword. While the human rights community was able to expand its issue areas and reach out to the wider public, at the same time it had to endure its weakened foundation due to the ever-accelerating proliferation of rights claim. In any event the raised visibility and normalization of interest-group politics had far more affinity with the counter-discourse of human rights than with the traditional discourse. The proliferation also allowed an opening of a political window through which the counter-discourse was able to argue forcefully for more possessive rights and for the inherent right to pursue one's material gain under the banner of 'rugged individualism' and 'rational' self-seeking. 


\section{Domination of Neoliberal Economic Trend}

The radical shift towards the neoliberal economic paradigm in the last two decades in Korea was perhaps the most important structural factor for the differing evolution of human rights concepts after the democratization. In order to fully grasp the significance of neoliberal economic turn on human rights discourse and movement one needs to understand the broader political and historical context. First, Korea's democratic turning point in the late 1980s was soon followed by the collapse of socialist bloc and the end of the Cold War. The seismic international upheaval sent a considerable shock wave to the political compass of the pro-democracy movement, whose ideological alternative to the former authoritarian rule had spanned a vast spectrum between liberal democracy and Marxism-socialism. Second, the old 'developmental state' model was given a new lease of life despite the democratic restoration, as the economic policy continued following more or less the same pattern with an increasing orientation towards liberalization. It may be accurate to state that no government in Korea - before or after the democratization - has successfully steered the nation away from the prevailing export-oriented, growth-centered developmental strategy. The growth-centered policy has left an indelible mark on the nation's development ethos which is based on the mantra of "Growth is good, more growth is better." Third, the election of the first post-transitional democratic government of Kim Dae-Jung coincided with the cataclysmic Asian financial crisis in the 1997-8. As a result the economic agenda of the new democratic government was ironically driven by policy initiatives to accelerate the structural adjustment and liberalization process, which had actually been set in motion in the previous government. The experience may resemble the much quoted Polish graffiti: "We wanted democracy but we ended up with the bond market." Fourth, political openness and cultural internationalization following the democratization were coupled with the general fear of economic globalization, which was further enhanced by underlying nationalistic sentiment - perhaps not surprising for a country that bore the harsh brunt of unbridled neoliberal globalization throughout the period of 'democratic' governments.

The response of the traditional human rights movement to this economic shift was by and large critical and resistant. Although the point of reference for the critique varied widely ranging from the outright rejection of the new trend to critical engagement, one common theme which ran through 
the whole debate was the effect of globalization on poverty and widening inequality. In this regard Lim's (2006a) assertion that human rights movement must be first and foremost a fight against poverty in a rapidly globalizing era was testament to a paradigm shift from the predemocratization era when the human rights struggle was exclusively an antithesis of authoritarian rule in a political sense. This shift in emphasis is clearly observable from the human rights community. A survey of human rights NGOs in Korea revealed that the primary focus of their activity at the time of investigation was to expose the extent to which people suffered in the wake of economic crisis, that human rights NGOs engaged in efforts to bring international pressure to bear on the government to solve problems related to poverty, and that the NGOs called for necessary measures to establish social welfare safety net for those who are most at risk (Kim, 2004). Escalating poverty was closely linked with the situation of workers who were subject to vagaries of the capital fluctuation and unlimited competition. Among the harshest for workers under these circumstances was the arrest and imprisonment of workers on charges of unlawful obstruction of business and violent disruption of production. Irregular workers usually comprised the largest portion of those who were legally sanctioned against the backdrop of flexible labor policy, strict adherence to law-and-order policy, and alleged bias of prosecutorial power (Lee, 2006). It is noteworthy that women in particular are found to have been subject to multiple suffering under globalization condition, which is more gender-specific and more discriminatory. According to Shim (2006a), women experienced deeper polarization, steeper poverty and more irregular work opportunities than men. In tandem with these problems, however, came women's and the public's raised concern for human rights which in turn highlighted and problematized the discrimination against and violence on women, and made those hidden suffering visible 'social problems'. South Korea is no exception in terms of exploitation of women through human trafficking in a more globalized world. This was compounded by a geo-political situation of the country where large-scale U.S. troops are stationed. The influx of women into these military bases from places like the Philippines and former Soviet republics made the already unbearable condition of women more internationalized and more difficult to contain (Lee, 2004a). The resultant international pressure and the collaborative effort of domestic human rights groups forced the government to legislate a law on regulating sex industry and on making prostitution a punishable criminal offense for both parties, although the Prevention Act of Prostitution was not without its problems 
(Kim, 2008a). The recognition that globalization has brought on a plethora of economic, social and cultural problems, has in turn opened a new opportunity for social movements in Korea. Human rights movement along with environmental movement took this opportunity to take part in transnational activism and to help create and influence transnational public sphere (Lim and Kong, 2006). In short the traditional human rights community responded to neoliberal globalization with the diagnosis that the latter is a reactionary trend reversing the history back to the early phase of unhindered capitalism, and advocated that the full-blown struggle to reclaim 'sociality' from neoliberal onslaught should be the most urgent task of human rights movement in the country (Lim, 2007). Related to this there has also been a surge in interest within human rights community on the rights-based corporate social accountability (Cho, 2008a).

One of the most interesting aspects of neoliberal globalization in relation to human rights is that it has actively been engaged in formulating a more coherent counter-discourse of human rights. This is quite different from the previous counter-discourse which tended to be reactive, defensive or merely speculative. The new counter-discourse claimed that free market alone could deliver true fulfillment of human rights through encouragement of individual's competitive instinct and the unprecedented material improvement. This kind of 'possessive human rights' concept had as its central tenet the principle of property rights from which follows the notion of other rights, hence the crystallization of an atavistic 'vertical' dimension of human rights. Lee (2003) criticized that this kind of human rights concept was spurious in nature. Another notable development was the application of legal logic to support the neoliberal concept of human rights. This was one of those classical examples where neoliberal predominance was given intellectual justification (Cho, 2008b; Park, 2008; and for a more critical understanding, see Park, 2007). The impetus for a vigorous counter-conceptualization of human rights mainly came from the business-related associations such as Federation of Korean Industries and economists of neoliberal leaning. It should be made clear that this 'minimalist' understanding of human rights not only is not conducive to the accepted consensus on the inclusive 'indivisibility' principle of human rights, but also refuses to acknowledge the norms and standards of the International Covenant on Economic and Social Rights that South Korea had ratified in the early 1990s. The counter-discourse has not satisfactorily answered to the basic question of whether to equate the discourse of property-centered bare-bone rights with the internationally recognized human rights principles would be acceptable in today's world. 


\section{The North Korean Human Rights Issue}

The problem of human rights in North Korea and the outside concern about it are not a new phenomenon. It may be possible to write off South Korean government's criticism towards the North during the height of the Cold War as bordering on a political propaganda, but there had existed concern on the issue from an external observer's viewpoint (cf. Cumings, 1986). Interest in and publicity about human rights situation in North Korea started to take a clearer shape in the 1990s when a series of famine struck the country with devastating results including deaths, starvation, chronic malnutrition, diseases like tuberculosis, displaced people and 'economic refugees'. Reports, intelligence and sometimes unconfirmed 'horror' stories abounded depicting the tragedy that befell the general population of the country. Plight of North Koreans seeking food and shelter in the Northeast China was put on the international agenda, and North Korean refugees coming to and settling in South Korea have become a normal part of social life here. Alongside this phenomenon of humanitarian nature emerged sketches of human rights atrocities inside North Korea that echoed familiar repertoire of totalitarian repression such as surveillance and control of population, labor camps for political prisoners and a very low level of citizens' liberty. Human rights situation in North Korea have all the ingredients of a heavily politicized debate in terms of tension in the divided Korean peninsula, the nature of its cause and the controversial nature of its proposed solution, its regional ramifications involving South Korea, the U.S., China, Russia and Japan, international political implication at the U.N. level, etc. The North Korean human rights situation has become one of the most fiercely debated subjects in South Korea in the last several years. The stark polarity in opinion on the issue means that even the very basic aspect of the debate has not been agreed upon, let alone solved. For example, it is not clear whether public concern and interest on North Korean human rights situation was aroused purely on the grounds of humanitarian concern or were motivated by the so-called 'constitutional legitimacy' logic, i.e. some South Koreans' insistence that North Korea is an unlawfully occupied land by enemies, thereby the expression of human rights concern on North Korea is an appropriate and legitimate part of South Korea's 'domestic' policy. Those who took the latter view tend to accuse the National Human Rights Commission for its lack of proper attention and efforts to 'solve' the problem. 
If neoliberal economic environment provided the counter-discourse of human rights with a vertical conception of human rights, i.e. intellectual justification of a certain set of human rights principles, the North Korean human rights issue has become an important horizontal element - an indispensable issue area within the whole gamut of human rights movements - for the counter-discourse. It is the issue of North Korean human rights that explicitly opened a fundamental schism between the traditional human rights movement and the newly emerging counter-discourse. Indeed the counter-discourse took a firm shape as a visible alternative challenger to the traditional human rights movement through the North Korean human rights issue.

Based on normative arguments Kim (2005c; 2006b) usefully classified the main controversies surrounding the issue in three parts: first, a debate over primacy between human rights and sovereignty; second, a debate over priority of civil rights versus priority of the right to life; and third, a debate over the relevance of individual human rights versus the significance of the right to peace. In each category there are disagreements between the traditional human rights movement and the new human rights movement. In contrast to the case of neoliberal economic trend it was the new movement that took the active initiative on the North Korean case. In a comprehensive overview of the controversy Woo (2006) suggested that there were five areas of disagreement over the North Korean human rights issue between the two sides. First, the concept of human rights itself is contested between a universal human rights approach and a relativistic understanding of human rights. Second, disagreement over the causes of human rights exists between an endogenous explanation and an exogenous argument. Third, how to solve the problem has also become a fiercely contested question, which includes (a) pressure on North Korea including an attempt to a regime change, (b) a policy of prioritized peace-building followed by gradual realization of human rights, and (c) a parallel and concurrent approach to human rights, economic support and peace. Fourth, a question over whether humanitarian assistance can produce a long-term improvement of, or at least a removal of hindrance to, the achievement of human rights in North Korea remains unresolved. Last, whether the U.S.s North Korean Human Rights Act of 2004 could be an effective policy leverage to solve the issue is another controversial point. Again the traditional human rights movement and the new movement have clashed over each one of the above points.

The new movement's proactive approach is well reflected in the sheer amount of literature it has generated. For example, Youn (2005) justifies an 
active outside intervention on North Korea with an analysis on forced labor camps for political prisoners. The existence of such a totalitarian institution alone is said to justify the more principled, active or even aggressive approach. In the same vein Han (2006) describes human rights violation in all its forms in North Korea including abuses in civil and political rights as well as arbitrary deprivation of people's right to feed themselves. Huh (2005) is scathing about the lack of sufficient public concern over the North Korean human rights situation and suggests that the more attention it receives the more likely it could be improved. For those who are taking a hard-line stance and who are supportive of North Korea's democratization, a regime changeapproach appears to be virtually the only solution for improving human rights situation in the country. Lee (2005a) argues that external intervention, i.e. American involvement aiming democratization is the only viable option for the North Korea's human rights improvement. It is also suggested that the overthrow of Kim Jong-Il regime should be a guiding principle for organizing human rights movement on behalf of North Korean people (Hong, 2006). Another characteristic of the new movement is that it often describes itself as an internationalist in that it regards international intervention (American assistance and involvement in particular) as an integral part of any solution (Kim, 2005a; 2005b) and that it seems to believe in the ultimate effectiveness of external coercion and pressure (Kim, 2008b). Interestingly, the reaction of North Korea to the outside intervention and pressure was not only outright rejection and backlash (perhaps predictably), but also to accept some flexible approaches including selective accommodation, domestic legislation and attitudinal change (Lee, 2007d). The implication of this finding is that some externally induced changes may be possible even in the seemingly most impregnable regimes like North Korea. The new human rights movement's stance may have been bolstered by the George W. Bush administration's equally hard-line policy towards North Korea (Kim, 2006a). Those who are major actors in raising North Korean human rights issues comprise a small number of long-standing human rights groups, the so-called New Right Movement, some church-supported NGOs, some right-wing media and intellectuals with neoconservative views.

The response of the traditional human rights movement to the North Korean human rights issue was by and large the opposite to that of the new movement. The former considers sovereignty of North Korea as an important starting point of the debate, thereby rejecting external intervention as dangerous and ineffective, emphasizes the right to survival and right to peace, believes that reports of human rights situation in North Korea tends to 
be exaggerated or inaccurate, regards the United States as the problem-giver in the first place rather than the problem-solver (Kang, 2005), and finds solution in the form of humanitarian assistance, more cooperation between the two Koreas and reconciliation. There is an indication that the traditional human rights movement took a skeptical position from the early phase of the debate over the factual ascertainment of North Korean human rights situation. It seems to view the new movement's argument for intervention with suspicion that there are some hidden ulterior motives besides the improvement of human rights of the country. Moreover, it was argued that the idea of 'right to subsistence' - hence, more humanitarian assistance and engagement with the North - tends to hold sway in the East Asian context (Han, 2007). It must be noted, however, that the traditional human rights movement has been criticized as having acted with a double standard that it did not take as universal and principled stand towards North Korea as it had done towards authoritarian rule in South Korea in the past. This does not necessarily mean that there is no interest or concern from its side; the reverse may be true (cf. Suh, 2007a). But critics of the traditional human rights movement point out that its problem lies in its general reluctance to face up to the reality, let alone confront the problem, with its usual vigor and moral fortitude. As a last analysis, it is worth noting that recently there is an indication of some kind of mutual accommodation and convergence on the issue (Jhe, 2009; Yang, 2007), with more practical and evidence-based approaches (Choi and Cho, 2008; Shim, 2006b). It may then be safely stated that the difference between the two sides is now more of a matter of emphasis and attitude than of fundamental disagreement.

\section{Two Concepts of Human Rights}

As has been explained, by the time the military dictatorship came to an end the concept of human rights in Korea was based on the classical notion of struggle for liberty and equality, something very close to the spirit and tone of the Preamble of the Universal Declaration of Human Rights. Understandably the term 'human rights' was almost always associated with democracy and pro-democracy movement at the time; human rights were indeed seen to have a collocated relationship with democracy both as a qualifier of and as a catalyst for democracy (Cho, 2006). This line of interpretation was within the firm grasp of traditional pro-democracy human rights movement. The experience of last twenty years, however, has changed 
the rather monistic approach of the traditional human rights discourse. But at the same time an alternative discourse of human rights, which had originally started as a justificatory rhetoric of conservative ideology, has risen to some prominence, after having reinvented itself as a distinctive, if idiosyncratic, voice of human rights from a right-wing perspective. Therefore, it may be possible to claim that there now exist two rather diametrically placed conceptions of human rights in contemporary Korea.

It has been argued that the reason for and process of the emergence of two different concepts of human rights can be attributed to the four contingent developments, or contributing parameters, in the intervening years. The parameters have helped redefine conceptual contours of the traditional human rights movement and have also allowed room for a new concept of human rights to emerge. Owing to the institutionalization of human rights the traditional discourse has had to formalize and rationalize its concept of human rights according to rules and regulations of the official governing structure. The institutionalization has also enabled the counterdiscourse to attack the traditional discourse not on the basis of human rights principles per se but of political accountability, thereby securing some foothold for its own existence. The expansion of human rights issue areas and the concurrent proliferation of rights claims steered the traditional discourse away from the correlative twin concept of 'rights-duty' towards the concept of de-monopolizing vested interests at all levels, creating a whole new set of human rights movements which are civil society-led and 'maximalist' in character. In the process the strong link between human rights and democracy was progressively de-coupled before it was reversed to some extent after the advent of Lee government. Interest groups of all kind quickly took advantage of the situation the proliferation of rights claim created, adding additional voice to the self-seeking rights concept of the counterdiscourse. The neoliberal economic paradigm triggered the traditional discourse's deeper and broader commitment to economic rights and social justice, while the paradigm provided the counter-discourse with a stimulus to formulate a 'minimalist' human rights concept along the lines of a 'free market plus law-and-order' model, thereby furnishing a vertical dimension of human rights of its own. The North Korean human rights issue has left the traditional discourse with an obvious lacuna in terms of an important issue area within the 'horizontal' dimension of human rights movements. The deficit has also left a distorting impact on the hitherto 'universal' human rights concept of the traditional discourse. The counter-discourse has vigorously pushed the North Korean issue into the international as well as 
domestic human rights agenda, justifying it as one of the most urgent human rights issues of our time.

The traditional discourse has been driven mainly by civil society actors and human rights activists in the pro-democracy movement, whilst the new discourse is the aggregation of activities by various interest groups, corporate apologists, the so-called New Right movement, certain church-affiliated NGOs, and conservative media. Although the new discourse lacks cohesiveness and still remains a less than coherent and rather nebulous concept due to its heterogeneous composition, nevertheless it has managed to form a recognizable shape with significant influence on the human rights scene internationally as well as domestically.

To what extent do these two concepts resemble or differ from the common denominators of human rights concept described in the introduction section? In terms of ontology, the concept of the traditional discourse seems to faithfully maintain that human dignity and equal worth for everyone must be respected regardless of any other considerations. This position tends to produce an inevitable tendency towards maximization of rights claim. The concept also seems to support that human beings show interest- and/or liberty-seeking propensity depending on the circumstances, in terms of human nature. In terms of the role of society, the concept of the traditional discourse rightly demands that the state has to fulfill its duties of self-restraint as well as of positive duties to the fullest possible extent. Moreover, the concept emphasizes that civil society participation is a crucially important element for putting pressure on the state for the realization of human rights. In terms of epistemology and method for attainment of human rights the traditional discourse embraces all the legal and non-legal compliance mechanisms. International solidarity, however, is not something the traditional concept has sought in the case of North Korean human rights. For example, there is no palpable sign yet that it has attempted to closely collaborate with various international actors including the United Nations' Special Rapporteur on North Korea.

The concept of the counter-discourse contrasts sharply with the traditional one. In terms of ontology, it is not clear whether the concept unequivocally accepts the universal value of human rights for everyone regardless of, among others, political belief, although it often uses the 'universalist' rhetoric in the context of North Korean human rights. It may be difficult to reconcile this kind of delimited concept with the modern human rights discourse in a usual sense. In terms of human nature, the counterdiscourse endorses the pursuit of private interests as legitimate concern of 
'human rights' and places emphasis on liberty of North Koreans. In terms of the role of society, the new concept is of the firm belief that the state should act as the strict enforcer of law and order, and seems to believe that the state's positive duties in terms of economic and social rights clearly do not represent its legitimate role for the protection of human rights. Finally, in terms of epistemology and method for attainment, the counter-discourse advocates legal as well as international sanctions and intervention particularly with regard to North Korean human rights. Its position, however, is rather selective and inconsistent, since it rejects, for example, recommendations of the international human rights community to revise or abolish the National Security Law, which is seen to be a major source of restraint for citizens' political freedom in South Korea.

The corollary of this differing evolution of human rights discourse is a clear bifurcation between the two seemingly irreconcilable concepts, i.e. the maximalist, civil society-oriented concept versus the minimalist, illiberal internationalist human rights concept. Therefore it may well be that the future of human rights in Korea will be dependent, at least partly, on the interaction and rivalry of the two alternative human rights concepts, and on their future evolutionary trajectory.

\section{Concluding Remarks}

The sweeping overview of the human rights landscape in contemporary Korea shows that during the last two decades the two distinctive concepts of human rights have emerged and competed with each other, and that both of them have exerted substantial influences on societies in their own ways. Although other conceptualizing positions of human rights certainly do exist, the two opposing concepts identified in this paper appear to be most significant in terms of their political impact and intellectual challenge. As a final analysis, I shall provide some observations as a way of recapping the important components of the argument put forward so far.

First, both concepts of human rights reveal some degree of inherent contradiction and tension within their respective conceptual reasoning. For the counter-discourse, it would be hard to justify that a modern-day concept of human rights can be constructed on the basis of a severely atrophied and anachronistic understanding of human freedom. The development of human rights at the frontline of a common international struggle during the past century means that it is now almost pointless, if not impossible, to build a 
'stand-alone' concept of human rights detached from a fuller notion of democracy, increasingly expanding standards of rights, and the global justice movement. In order to avoid a partial concept of human rights, one needs to engage with the international human rights discourse in its totality and to produce as dynamic and comprehensive a human rights concept as possible (Gready, 2003). Furthermore, for both the counter- and the traditional human rights movements, the North Korean human rights issue needs to be addressed on a more constructive theoretical/practical basis, separated from the heavily politicized, partisan approaches of today. Therefore both concepts of human rights should recognize that neither of them can fully contribute to the building of ultimate human security without reconfiguring some of their assumptions and orientations. It may be fair to suggest, however, that if some contradictory characteristics of the traditional human rights discourse are derived more from a practical consideration, those of the counter-discourse may be traced to its deeply-held conviction, hence the intrinsically problematic nature of the latter.

Second, the fact that the differing human rights concepts have been formulated through the periods of critical socio-economic-political change demonstrates that the idea of human rights - and its conceptual mould - is a 'political' ideal after all and a modernist project of human liberation. This leads to the understanding that attempting to reduce the ideal of human rights to the question of compliance of internationally codified legal standards is but the one dimension of multilayered processes in which diverse conceptual as well as practical expressions of human rights are continuously in competition and reformulated. This in turn illustrates the point that human rights are, and will be, determined through political struggles among various social actors with different levels of controlling leverage and with different visions of a 'good' society; disagreement over the concept of human rights can then be best viewed against the background of this ongoing struggle.

Last but not least, we may need to search for some 'overlapping consensus' on the idea of human rights, although a complete convergence of different concepts may never be achievable. The common foundation for the 'overlapping consensus' of human rights cannot entirely be built on the 'rule of law' alone, since it is the idea of 'rule of law' itself that has become a focus of interpretative dispute and political conflict, at least in the contemporary Korean context. It is important therefore that the useful starting point for the common foundation of human rights needs to be envisioned through agreeing upon a kind of 'public philosophy' of human rights, in addition to 
the existing legal/constitutional standards (cf. Schumaker, 2008). A properly devised public philosophy of human rights could then function as an undisputable common ground for human freedom at the same time as allowing room for conflict and competition between different concepts of human rights, a process which resembles the normal democratic political process - no matter how arduous that may be.

\section{References}

Ahn, B. J. 2004. "Problems with Attempting to Correct the Past History." Philosophy and Reality 63: pp. 26-37.

Ahn, K. H. and B. H. Jang, eds., 2002. Conscientious Objection. Seoul: Saramsaenggak. Amnesty International. 1986. South Korea: Violations of Human Rights. London: AI.

Asia Watch Committee. 1987. A Stern, Steady Crackdown: Legal Process and Human Rights in South Korea. Washington, D.C.: Asia Watch Committee.

Beetham, D. 1999. Democracy and Human Rights. Cambridge: Polity Press.

Bell, D. A. 1996. "The East Asian Challenge to Human Rights: Reflections on an East West Dialogue." Human Rights Quarterly 18: pp. 641-667.

Carter, A. 2005. Direct Action and Democracy Today. Cambridge: Polity.

Cha, S. J. 2005. "Discrimination and Human Rights Protection of Women with Disabilities." Journal of Civil Law 13(2): pp. 133-166.

Cho, H. Y. 2000. "Democratic Transition and Institutional Politics, People Politics and Citizen Politics." Economy and Society 46: pp. 170-198.

Cho, H. J. 2002. "Human Rights in Korea at the Crossroads: A Critical Overview." Korea Journal 42(1): pp. 204-227.

. 2006. "Human Rights as a Qualifier and a Catalyst for Korea’s Democracy." In Xinhuang X., ed., Asian New Democracies: The Philippines, South Korea and Taiwan Compared, Taipei: Taiwan Foundation for Democracy Foundation. pp. 179-204.

2008a. "A Preliminary Study on Human Rights-Based Corporate Social Accountability." The Journal of Asiatic Studies 51(3): pp. 128-160.

Cho, J. H. 2008b. "The Comment on Function and Role of National Human Rights Commission of Korea." Korean Constitutional Law 14(2): pp. 67-97.

Cho, K. J. 2007. "Outcome of Surveys on Human Rights of Middle and High School Students in 2006." Korean Journal of Youth Studies 14(3): pp. 189-216.

Cho, K. B. 2008c. "Neoliberalism, Intensification of Capital Power and Crises of Workers' Human Rights." Democratic Legal Studies 38: pp. 39-68.

Choi, D. S. and Cho Y. J. 2008. "Changing Issues and Future Prospects of North Korean Defectors." North Korean Studies Review 33(2): pp. 87-119.

Chun, K. O. 2008. "Policies for Human Rights Education in Schools and College- 
Middle School Partnership." Journal of Korean Political Science 42(4): pp. 189212.

Cranston, M. 1967. "Human Rights, Real and Supposed." In D. D. Raphel, ed., Political Theory and the Rights of Man. Bloomington, Indiana: Indiana University Press. pp. 43-53.

Cumings, B. 1986. "Human Rights in the Democratic People's Republic of Korea." In Asia Watch, ed., Human Rights in Korea. Washington D.C.: Asia Watch Committee. pp. 340-364.

Donnelly, J. 1982. "Human Rights and Human Dignity: An Analytical Critique of Non-Western Conceptions of Human Rights." The American Political Science Review 76(2): pp. 303-316.

. 2003. Universal Human Rights in Theory and Practice. 2nd Ed. Ithaca, NY: Cornell University Press.

Fagan, A. 2009. Human Rights: Confronting Myths and Misunderstandings. Cheltenham: Edward Elgar.

Fraser, N. and Axel H. 2003. Redistribution or Recognition?: A Political-Philosophical Exchange. London: Verso.

Fredman, S. 2008. Human Rights Transformed: Positive Rights and Positive Duties. Oxford: Oxford University Press.

Gearty, C. 2006. Can Human Rights Survive? Cambridge: Cambridge University Press.

Grand National Party Spokesperson. 2004. "Political Approach to Past History must be Stopped." Korean Unification 9: p. 58.

Gray, K. 2004. “The 'Underclass' of Migrant Workers in Korea.” The Journal of Asiatic Studies 116: pp. 97-128.

Gready, P. 2003. “The Politics of Human Rights.” Third World Quarterly 24(4): pp. 745-757.

Han, K. H. 2006. "Human Rights Situation in North Korea." Philosophy and Reality 68: pp. 80-91.

Han, H. K. 2009. "Past History and Historical Debate in the Lee Myung-bak Presidency." History and Reality 69: pp. 3-15.

Han, S. J. 2007. "Intercultural Dialogue and a Balanced Approach to Human Rights in North Korea." In K. D. Park and S. J. Han eds., Human Rights in North Korea: Toward a Comprehensive Understanding, Bundang: The Sejong Institute. pp. 237280.

Heo, S. M. 2008. "Suggestions on Human Rights Education for Formation of Human Rights Culture." Social Studies Education 47(4): pp. 153-181.

Hong, J. P. 2006. "Organizing and Focusing North Korean Human Rights Movement into Anti-Kim Jong-il Regime." North Korea 412: pp. 59-64.

Hong, S. J. and J. H. Sung. 2003. "A Study on the Self-Identity and Human Rights of Women with Disabilities: Focused on Construction of Group Identity as Community and Human Rights." Asian Women 42: pp. 47-83. 
Huh, M. H. 2005. "Should we Keep Silent about Human Rights Issues in North Korea." North Korea 407: pp. 67-74.

Ishay, M. R. 2004. The History of Human Rights: From Ancient Times to the Globalization Era. Berkeley: University of California Press.

Jang, S. C. et al. 2002. "Democratization and Interest Groups: State, Non-Profit Organization, and Social Capital." Trends and Perspectives 54: pp. 156-185.

Jhe, S. H. 2009. "North Korean Human Rights: Their Concrete Range and Options for Improval [sic]." The Journal of Strategic Studies 45: pp. 77-123.

Ju, S. Y. 2007. "No Justification of Existence for the National Human Rights Commission." Korean Unification 1: p. 76.

Jung, K. S. 2006. "Dissolution of Settlement Village and Network of Migration in Hansen's Disease Ex-Patient Communities." Society and History 69: pp. 43-81.

Kang, J. K. 2005. "Responsibility of the U.S.A. for the Human Rights Problems in North Korea." Reunification of Korea 259: pp. 68-71.

Kim, D. J. 1994. "A response to Lee Kuan Yew: Is Culture Destiny?: The Myth of Asia's Anti-Democratic Values." Foreign Affairs 73(6): pp. 189-194.

Kim, M. H. 2001. "Democracy and Human Rights in Korea." Journal of East Asian Studies 1(2): pp. 89-119.

Kim, N. 2004. "Neo-Liberalism, Poverty, and the Role of Human Rights NGOs in Korea." The Korean Journal of Humanities and the Social Sciences 93: pp. 67-99.

Kim, J. I. 2005a. "Human Rights Situation in North Korea and International Society 1." North Korea 400: pp. 152-157.

2005b. "Human Rights Situation in North Korea and International Society 2." North Korea 401: pp. 122-127.

Kim, W. S. 2005c. "The Situation and Prospect of Discourse on North Korean Human Rights." Society and Philosophy 9: pp. 99-129.

Kim, S. A. 2006a. "Bush Administration's Human Rights Policy on North Korea." The Korean Journal of Political and Diplomatic History 27(2): pp. 345-372.

Kim, W. S. 2006b. "The Examination of Normative Arguments in the Discourse on North Korean Human Rights.” North Korean Studies Review 10(1): pp. 75-95.

Kim, A. R. 2008a. "Prostitution in the Age of Globalization and Korean 'Preventive Act of Prostitution." Economy and Society 79: pp. 254-273.

Kim, J. I. 2008b. "Human Rights Situation in North Korea cannot be Achieved without Its Regime Change.” North Korea 434: pp. 94-103.

Kim, J. Y. 2008c. "A Study of Human Rights Protection for the Disabled." Journal of Human Rights and Welfare 4(9): pp. 131-155.

Kim, K. S. 2009a. "Collective Selfishness shown to the Construction of a Sports Facility for the Disabled." The Korea Journal of Sports Science 18(3): pp. 359-369.

Kim, S. K. 2009b. "A Study on Human Rights of Student Athletes and on the Protection of Educational Right." Sports and Law 12(1): pp. 11-34.

Kwak, N. H. 2002. "National Human Rights Commission at Work: A Critical Reflection.” Korea Journal 42(3): pp. 194-218. 
. 2006. "The Vision and Direction of National Human Rights Commission." Public Law 35(2-2): pp. 177-188.

Kwon, I. S. 2009. "Analysis of Sexuality within the Army, Focusing on Sexual Desire, Masculinity and Homosexuality." Economy and Society 82: pp. 38-65.

Lee, G. C. 2003. "Capital, Pseudo-Human Rights and Neoliberal Globalization." Literature and Frontier 11: pp. 174-191.

Lee, J. O. 2004a. "The Globalization of Human Rights and the Human Security of Women in Sex Industry." Korean Journal of Women's Studies 20(1): pp. 195-227.

Lee, N. S. 2004b. Conscientious Objection and Civil Disobedience. Seoul: Greenbee.

Lee, Y. H. 2004c. "Democratization and Social Conflicts: Focusing on Social Conflicts and Public Policies." Trend and Prospect 61: pp. 36-67.

Lee, K. B. 2005a. "Support for Democracy in North Korea as the Solution for its Human Rights Problem.” Reunification of Korea 6: pp. 19-22.

Lee, K. S. 2005b. "Premodern Military Culture and Human Rights of the Soldier." Democratic Law Studies 28: pp. 160-180.

Lee, G. R. 2006. "Human Rights of Imprisoned Workers and Democracy in Korea." Situation and Labor 17: pp. 97-105.

Lee, C. H. 2007a. "The Mental Health Law and the Human Rights of Persons with Medical Disorders." Korean Constitutional Law 13(4): pp. 229-258.

Lee, H. J. 2007b. "Five Years of Korean National Human Rights Commission: Evaluation and Prospect; Effects and Limits of Policy Recommendations of NHRCK - Focused on the Effects to the Criminal Justice System." Democracy and Law 33: pp. 59-91.

Lee, S. M. 2007c. "The Conscientious Objection to the Military Service and the Freedom of Conscience." Korea University Law Review 49: pp. 911-933.

Lee, W. W. 2007d. "International Human Rights Pressure and North Korea: A Critical Analysis on Its Perception and Reactions." Korean Journal of International Relations 47(1): pp. 215-233.

Lee, J. E. 2008. “The Formation and Institutionalization of Human Rights Discourses after the Liberation, 1945-1970's." Unpublished PhD Thesis. Seoul National University.

Lim, C. H. 2006a. "Poverty and Human Rights." Yeungnam Law Journal 12(1): pp. 45-58.

Lim, J. B. 2006b. "Korean Society and National Human Rights Commission of Korea." Public Law 35(2-2): pp. 1-29.

Lim, C. H. 2007. "Change and Subject of Human Rights Movement in Korea." Yeungnam Law Journal 24: pp. 45-67.

Lim, H. C. and S. Kong. 2006. "The Logic of Global Civil Society: Transnational Mobilization Strategy of SMO (Social Movements Organizations) in Korea." The Korean Journal of Sociology 40(2): pp. 1-36.

Nam, C. S. 2007. “The Meaning and Main Contents of the Act to Prohibit Discriminating Against People with Disabilities." Health and Welfare Forum 127: 
pp. 23-33.

Oh, Wan-Ho, Min-shik Choi, Yong-mok Kim, Sang-woo Park, and Chang-soo Lee.

2007. "Human Rights Movements at Local Level." Human Rights 1: pp. 17-20.

Park, R. G. 2007. "Neoliberalism, Collapse of the State of Rule of Law and Human

Rights Movement." The Radical Review 34: pp. 10-25.

Park, C. I. 2008. "Rule of Law and Economic Development." Justice 106: pp. 39-79.

Ranard, D. L. 1980. "Korea, Human Rights and United States Foreign Policy." In T. J.

Farer, ed., Toward a Humanitarian Diplomacy: A Primer for Policy. New York:

New York University Press. pp. 177-226.

Schumaker, P. 2008. From Ideologies to Public Philosophies. Oxford: Blackwell

Publishing.

Sears, R. V. 2005. “The Left: From Hope to Sneers in Only 25 Years.” Policy Options

March-April: pp. 19-26. <http://www.irpp.org/po/archive/mar05en/sears.pdf>

(Access: October 6, 2009).

Seo, D. J. 2005. "Human Rights, Citizenship and Sexuality." Economy and Society 67: pp. 66-87.

Seol, D. H. 2005. "Migrant Workers and Human Rights." Democracy and Human Rights 5(2): pp. 39-77.

Shim, Y. H. 2006a. "Globalization and Women's Security in Korea." Gender and Society 5: pp. 11-52.

. 2006b. "Human Rights of Women in North Korea: Present State and Factors." The Journal of Asian Women 45(2): pp. 151-194.

Suh, B. H. 2007a. North Korean Human Rights: Theory, Practice and Policy. Seoul: Hanul.

Suh, J. S. 2007b. "Review and Prospect of Truth Seeking in the Past History." History and Criticism 80: pp. 46-79.

Stammers, N. 1999. "Social Movements and the Social Construction of Human Rights." Human Rights Quarterly 21(4): pp. 980-1008.

Steiner, H. J., Philip A., and Ryan G. 2007. International Human Rights in Context: Law, Politics, Morals. 3rd Ed. Oxford: Oxford University Press.

Teeple, G. 2005. The Riddle of Human Rights. Aurora: Garamond Press.

Woo, S. J. 2006. “On the Study of North Korea's Human Rights Issues.” Korean Journal of International Relations 46(3): pp. 189-212.

Yang, C. S. 2007. "North Korean Human Rights Issues from the Perspective of Mutual Legality." Public Law Journal 8(2): pp. 211-234.

Yoo, S. H. and Sun A. K. 2008. "Nursing Home Staff's Knowledge on the 2004 Revised Older Koreans Act for Elder Abuse, Reports of Elder Abuse and Attitudes about Sanctioning Mandatory Reporters." Social Welfare Policy 33: pp. 311-333.

Youn, H. 2005. "An Analysis on the Realities of Human Rights Policy and Prison Camps of the Political Criminals in North Korea." Reunification Strategy 5(2): pp. $172-228$. 
Zakaria, F. 1994. "Culture is Destiny: A Conversation with Lee Kuan Yew." Foreign Affairs 73(2): pp. 109-126.

CHO HYO-JE is Guest Professor of Sociology at Free University Berlin, and Professor of Social Sciences at SungKongHoe University Seoul. His research interests lie in the area of human rights discourse and practice, civil society, and democratic theory. Among his publications are Human Rights and Civic Activism in Korea (2005) and A Grammar of Human Rights (2007). Cho was a member of Policy Advisory Panel with the Ministry of Justice in Korea, and Human Rights Visiting Fellow at Harvard Law School. Address: Department of Social Science, SungKongHoe University, 1-1 Hang-dong, Kuro-gu, Seoul, 152-716, Korea [Email: hyojecho@ hotmail.com] 
